\title{
Sumbangan Pemikiran Filsafat Pendidikan Paulo Freire Bagi Sistem Pendidikan Tinggi Indonesia
}

\author{
Damianus Pongoh $^{\mathrm{a}, 1}$, Harol R. Lumapow ${ }^{\mathrm{b}, 2}$, Jeffry S. J. Lengkong ${ }^{\mathrm{c}, 3}$, Viktory N. J. Rotty ${ }^{\mathrm{d}, 4}$, \\ Ignatius J. C. Tuerah e, 5 \\ a, Sekolah Tinggi Filsafat Seminari Pineleng \\ b, c, d, e Universitas Negeri Manado \\ 1.dammy.pongoh@yahoo.com, ${ }^{2}$ Harolrlumapow@unima.ac.id, ${ }^{3}$ Jeffrylengkong@unima.ac.id, \\ 4viktoryrotty@unima.ac.id, ${ }^{5}$ javier@unima.ac.id
}

\section{A R T I C L E I N F O \\ Article History: \\ Submitted: 13 December 2021 \\ Revised: 8 February 2022 \\ Accepted: 20 February 2022}

Keywords: Education System; Mythology in

Education;

Liberation Process;

Problem-posing

Education

\section{Kata-kata Kunci: Sistem Pendidikan; Mitologi dalam Pendidikan; Proses Pembebasan; Pendidikan Hadap Masalah}

DOI:

https://doi.org/10.53396/media. v3i1.57

\begin{abstract}
:
This essay discusses the philosophy of education according to Paulo Freire, specifically methodology in the education process. The main question deals with the contribution of Freire's thought to the education system in Indonesia. Through literature review, the author underlines the concept of education as a process of liberation. Education is no longer regarded as a transfer of knowledge, but a process of change to create social structures that are more just and humane. Freire criticizes the bank-style education model which makes the teacher the subject, while the student as an object like an empty box to be filled. According to Freire, education should be developed as problem-posing education, namely education that aims at posing and discussing actual problems. It can be the main inspiration for the education system in Indonesia. This approach allows students to freely and creatively recognize their abilities and the reality of the problem objectively-contextually and respond appropriately to problems by creating productive and changing-oriented works.
\end{abstract}

\begin{abstract}
ABSTRAK:
Tulisan ini membahas pemikiran filsafat pendidikan menurut Paulo Freire, secara khusus metodologi pendidikan. Pertanyaan pokok dalam tulisan ini adalah apa sumbangan pemikiran Freire bagi pendidikan di Indonesia. Dengan tinjauan literatur, tulisan ini menggaris-bawahi sebagai sebuah proses pembebasan. Pendidikan bukan lagi sebuah transfer pengetahuan, melainkan proses perubahan dalam rangka menciptakan struktur-struktur sosial yang lebih adil dan manusiawi. Freire mengkritik model pendidikan gaya bank yang menjadikan guru sebagai subjek, sedangkan murid sebagai obyek seperti wadah kosong yang harus diisi. Menurut Freire, pendidikan dikembangkan sebagai problem-posing education (pendidikan-hadap-masalah), yakni pendidikan yang mengutarakan atau mengemukakan problem-problem aktual. Ini bisa menjadi inspirasi utama bagi sistem pendidikan di Indonesia. Pendekatan ini memungkinkan para siswa dan mahasiswa untuk secara bebas dan kreatif mengenal kemampuan diri dan realitas masalah secara obyektif-kontekstual dan merespons masalah secara tepat dalam bentuk karya-karya perubahan yang unggul dan produktif.
\end{abstract}

\section{Copyright $₫$ 2022, Author}

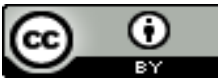

This work is licensed under a Creative Commons Attribution 4.0 International License 


\section{Pendahuluan}

Filsafat pendidikan memberikan sumbangan yang sangat berarti bagi perubahan paradigma pendekatan dalam proses pendidikan. Ada kesadaran baru bahwa proses pendidikan tidak bisa mengabaikan pengembangan dan penghargaan nilai-nilai manusia, misalnya nilai kebebasan. Sikap kritis telah diarahkan pada tendensi proses pendidikan yang justru membelenggu kebebasan dan menghantar subjek didik pada perbudakan. Salah satu pemikir yang berpengaruh dalam konteks filsafat pendidikan adalah Paulo Freire. Ia melihat pendidikan ini terutama sebagai sebuah proses pembebasan. Dalam tulisan ini, penulis hendak mendiskusikan metodologi pendidikan yang dikembangkan Freire. Namun, metode Freire tidak bisa dilepaskan dari pandangan filsafatnya sendiri perihal pendidikan. Oleh karena itu, dengan menggunakan tinjauan literatur, penulis hendak menguraikan pemikiran filsafat pendidikan Paulo Freire dan menemukan sumbangan pemikirannya bagi sistem pendidikan di Indonesia.

\section{Riwayat Hidup Paulo Freire}

Paulo Freire lahir pada tanggal 19 September 1921 di kota Recife, Brazil. Ayahnya, Joquim Temistockles Freire, seorang polisi militer, dan ibunya, Edeltrus Neves. Keluarga Freire adalah keluarga katolik yang baik, berasal dari golongan kelas menengah yang kemudian turut mengalami imbas masa Depresi Besar tahun 1929. ${ }^{1}$ Karena itulah Freire menyadari apa artinya lapar dari anak sekolah dasar. Pengalaman mendalam sewaktu masih bocah menyebabkan Paulo bertekad untuk mengabdikan hidupnya pada perjuangan melawan kelaparan supaya tidak ada anak lain yang akan merasakan penderitaan yang ia alami. Pengalaman tersebut membentuk keprihatinannya terhadap kaum miskin dan di kemudian hari ikut membangun pandangan dunia pendidikannya yang khas. Kendati berada dalam situasi sulit, Paulo Freire bisa mengenyam pendidikan sampai lulus di Universitas Recife pada tahun 1943. Di sana Freire belajar hukum, serentak memperdalam filsafat dan psikologi bahasa. Masa pendidikan ini akan memberikan panorama pemikiran filsafat Freire yang bertemakan pembaharuan dunia.

Setelah lulus kuliah, ia bekerja sebagai seorang guru di sekolah-sekolah menengah. Pada 1944 ia menikah dengan Elza Maia Costa de Oliveira, seorang rekan gurunya. Sebagai seorang guru, ia bekerja di antara orang-orang miskin yang buta huruf. Freire menerapkan bentuk pengajaran yang non-ortodoks yang belakangan dianggap sebagai teologi pembebasan. $^{2}$ Di Brasil pada saat itu, melek huruf merupakan syarat untuk ikut memilih dalam pemilu. Pada tahun 1959, Freire mempertahankan disertasi doktoralnya tentang Sejarah dan Filsafat Pendidikan.

Pada rentang tahun 1964-1978, Paulo Freire keluar dari Brazil karena kekacauan politik. Ia sempat ke Bolivia, Chile, Swiss sambil tetap menjalankan kegiatan mengajar di tempat-tempat ia pergi. Pada tahun 1979 ia kembali ke Brazil. Istrinya, Elza, meninggal

\footnotetext{
${ }^{1}$ Depresi Besar tahun 1929 adalah krisis ekonomi yang melanda dunia dan berlangsung sekitar 10 tahun. Peristiwa anjloknya bursa saham New York secara drastis mengawali masa ini; perekonomian dan industri negara-negara maju dan berkembang hancur.

${ }^{2}$ Paulo Freire, Pendidikan Sebagai Praktek Pembebasan (Jakarta: PT. Gramedia, 1985), 55-56.
} 
pada tahun 1986. Paulo menikah lagi dengan Maria Araujo. Ia meninggal pada tanggal 2 Mei 1997. 3

\section{Tema-Tema Filsafati Yang Mempengaruhi Pemikiran Paulo Freire}

Berikut ini adalah beberapa pemikiran yang mempengaruhi Freire. ${ }^{4}$ Yang pertama adalah personalisme Emmanuel Mounier (Filsuf Perancis, 1905-1950) 2). Personalisme adalah sebuah pandangan filsafat yang menekankan pentingnya pribadi-pribadi. Bagi Mounier, personalisme harus menjadi a fighting science yang tumbuh dari dan dinyatakan dalam struktur-struktur sosial-politik.

Yang kedua adalah Eksistensialisme Jean Paul Sartre (1905-1980). Filsuf Prancis ini mempengaruhi minat dan cita-cita Freire, yakni keotentikan atau kesejatian pendidikan yang sebenarnya merupakan wujud dari keotentikan dan kebebasan pribadi. Freire hendak mewujudkan manusia yang "ada-bagi-dirinya-sendiri", bukan manusia sebagai "ada-bagiorang-lain". Dengan gagasan seperti ini, Freire nanti mau mengkontraskan antara pendidikan gaya bank dengan tindakan sejati tentang pengetahuan (true act of knowing). Bagi Freire, hanya dengan true act of knowing ini, kebebasan individu menjadi mungkin terwujud.

Yang ketiga adalah Fenomenologi Edmund Husserl (Filsuf Jerman, 1859-1938). Gagasan Friere sering dikritik sebagai utopia karena perhatiannya yang besar terhadap struktur kesadaran manusia, dan dianggap mau mengubah realitas dunia semata-mata hanya dengan kesadaran. Namun, dari Fenomenologi Husserl, Freire mendapatkan inspirasi bahwa penelitian terhadap kesadaran merupakan prasyarat untuk memahami realitas. Diakui bahwa dengan fenomenologi, dapat tersingkap kondisi sosial dari kesadaran manusia dan kekuatankekuatan subjek yang berpikir untuk bertindak.

Yang keempat adalah Marxisme (Karl Marx, filsuf Jerman, 1818-1883). Tulisantulisan Freire, terutama Pedagogy of The Oppressed (Pendidikan Kaum Tertindas) mengandung pandangan tentang pemulihan kebebasan masyarakat dari dominasi kaum penindas. Yang penting bagi Freire adalah terciptanya masyarakat terbuka dan siap terhadap demokrasi sejati.

Yang terakhir adalah pemikiran Kristiani. Karena latar-belakang keluarga yang beragama Katolik, Freire banyak pula dipengaruhi oleh gagasan-gagasan kristiani. Apalagi, di Amerika Latin tumbuh Teologi Pembebasan yang mau mencoba menggerakkan masyarakat agama sebagai faktor pembebas manusia dari penindasan. Paulo Freire membuat sintesa baru atas pandangan banyak ahli. Inilah yang menjadikan pemikiran Freire bersifat utopia yang muncul dari proses keterlibatan Freire dalam memperjuangkan kaum tertindas. Hal ini ditempuh oleh Freire melalui Pendidikan.

\footnotetext{
${ }^{3}$ Paulo Freire, Pendidikan Kaum Tertindas (Jakarta: LP3ES, 1985). XII

${ }^{4}$ Budy Munawar-Rachman, "Pendidikan Sebagai Proses Transformasi Sosial:Teologi Perlu Belajar dari Filsafat Paulo Freire,” dalam Islam Pluralis Wacana Kesetaraan Kaum Beriman (Jakarta: PT. Raja Grafindo, 2004), 493-495.
} 
D. Pongoh, H. Lumapow, J. Lengkong, V. Rotty, I. Tuerah - Sumbangan Pemikiran Filsafat Pendidikan Paulo Freire Bagi Sistem Pendidikan Tinggi Indonesia: 103-115

\section{Karya-Karya Paulo Freire}

Pengalaman masa kecil dan keprihatinan kepada penderitaan dan kemiskinan terefleksikan dalam karya sosial Freire. Program pemberantasan buta huruf yang dia usung dijadikannya sebagai langkah awal menuju keadaan yang lebih besar dan serius. Membaca bagi Freire tak sekadar membaca tulisan, tetapi sampai kepada berkomunikasi dengan orang lain dan realitas lingkungan/dunia. Bagi Freire, mampu membaca berarti mengembangkan kesadaran, yakni mengerti apa yang dibaca, dan mampu menuliskan apa yang dimengerti. Karena itu, belajar membaca dan menulis tidaklah berarti hanya menghafalkan kalimatkalimat, kata-kata atau suku kata yang kosong dan tidak berkaitan dengan lingkungan eksistensial, tetapi juga mengembangkan kesadaran untuk menciptakan dan mencipta lagi untuk menangani lingkungannya.

Secara metodologis, yang unik dari metode Freire adalah kemampuan dirinya dalam melihat kenyataan bahwa di balik praktik pendidikan yang selama ini ada terselip ideologi paternalisme, kontrol sosial dan hubungan satu arah dari guru dan murid. Di sini terjadi ketergantungan murid kepada guru. Para murid terbelenggu (bahasa Freire "tertindas") yang mengondisikan mereka nanti bukan menjadi dirinya sendiri, tetapi menjadi seperti diri para guru atau apa yang diajarkan dan dikatakan oleh guru. ${ }^{5}$ Oleh karena itu, metodologi Freire telah mendorong refleksi ulang terhadap sistem pendidikan yang selama ini berjalan di Brazil. Di Brazil pendidikan pemberantasan buta huruf mempunyai arti politik yang penting. Hak seseorang untuk ikut-serta dalam pemilihan umum, misalnya dikaitkan dengan kemampuan seseorang dalam menuliskan nama atau identitas dirinya. Karena itu, tidak mengherankan jika setidak-tidaknya bagi Freire, pendidikan pemberantasan buta huruf harus berkaitan dengan peningkatan kesadaran politik bagi masyarakat, yang selama ini menjadi sekadar pendukung kepentingan minoritas yang berkuasa.

Upaya Freire untuk membebaskan masyarakat dari belenggu-belenggu politik kaum penguasa inilah yang akhirnya mengilhami terbitnya tiga buah karya utama, yakni Pedagogy of the Oppressed (1972), Cultural Action for Freedom (1972 dan Education for Critical Consciousness (1973), yang selanjutnya berganti judul dengan Education: The Practice of Freedom (1976). Melalui tulisan-tulisannya, Freire dikenal sebagai ahli pendidikan. Ia menekankan terutama -mengikuti istilah Freire sendiri- "pendidikan sebagai praktek pembebasan", dua entitas yang tak terpisahkan.

Dalam pandangan Freire, pendidikan bersifat ambigu. Di satu sisi, pendidikan dapat menjadi praktik penindasan, tetapi juga dapat menjadi praktik pembebasan pada sisi lain. Kedua kata ini, yakni penindasan dan pembebasan, merupakan pilihan kata yang sering kali dipakai Freire dalam konteks penegasan dirinya sebagai pendidik radikal. Dalam istilah yang lebih netral, misalnya yang dipakai dalam teks-teks sosiologi pendidikan, maka yang pertama (penindasan) bisa disebut dengan pendidikan liberal, sedangkan yang kedua (pembebasan) disebut dengan pendidikan radikal. Freire melihat bahwa selama ini pendidikan hampir selalu dilihat sebagai sebuah transformasi pengetahuan yang dilakukan dengan ideologi pendidikan yang tidak memihak. Menurut Freire pendidikan seharusnya

\footnotetext{
${ }_{5}^{5}$ Paulo Freire dkk, Menggugat Pendidikan Fundamentalisme Konservatif Liberal Anarkis (Yogjakarta: Pustaka Belajar, 1999), 439-440.
} 
direncanakan sebagai proses perubahan dalam rangka menciptakan struktur-struktur sosial yang lebih adil dan manusiawi. Pendidikan adalah tindakan politik (political act) yang terkait secara langsung dengan produksi, kesehatan, hukum dan seluruh rencana bagi masyarakat. ${ }^{6}$

\section{Filsafat Pendidikan Freire}

Bagi Freire, ada hubungan yang kuat dan menentukan antara filsafat (dalam arti umum dan secara khusus filsafat manusia) dan praktik pendidikan. Dalam kerangka itu, sistematisasi filsafat Freire penting dikedepankan:

- Realitas dialami manusia sebagai proses. Bagi Freire, menjadi manusia berarti menjalin hubungan dengan sesama dan dunia; menjadi manusia berarti mengalami dunia sebagai realitas objektif yang tidak tergantung kepada siapa pun. Manusia ada bersama dunia. Dengan demikian, manusia berproses dalam ruang dan waktu; manusia mempunyai dimensi historis. Itulah sebabnya, manusia tidak hanya terbatas pada suasana alami dan biologis saja, melainkan dapat berperan secara aktif dan kreatif. Manusia memasuki realitas dan mengubahnya, sehingga baik manusia maupun realitas berada dalam proses menjadi.

- Hubungan manusia dengan dunia berada dan terjadi dalam "kata". Kata merupakan ekspresi dari pikiran. Freire berpandangan bahwa fitrah manusia adalah menjadi subjek yakni pelaku yang sadar. Dunia adalah sesuatu yang harus digeluti secara kritis dan dengan sikap penuh daya cipta oleh manusia. Hal ini memerlukan pengembangan bahasa pikiran, yakni manusia mampu memahami dunia dan realitasnya dengan bekal pikiran dan tindakan-tindakan praksisnya. Perubahan dunia oleh karenanya merupakan kewajiban ontologis manusia. Maka, manusia dituntut untuk terus-menerus mengembangkan dirinya, sebagai makhluk yang mempunyai kesadaran. Kewajiban itu muncul, karena ia sebagai manusia, dan bukan binatang.

- Manusia berbeda dengan binatang. Binatang tidak berkarya. Ia hidup dalam keadaan yang tidak dapat mereka lampaui. Karenanya, ia hidup dalam suatu lingkungan yang hanya sesuai dengan dirinya. Binatang tidak dapat saling berhubungan satu sama lain. Sebaliknya, manusia bisa beraktivitas dengan refleksi dan tindakan. Manusia terarah kepada perubahan dunia. Maka, aktivitas manusia berupa teori dan praktik. Itulah sebabnya, manusia tidak boleh tereduksi menjadi teori melulu berupa verbalisme, atau menjadi praktik melulu dalam aktivisme. Bagi Freire, suatu revolusi sejati, yakni humanisasi struktur-struktur manusia, harus terlaksana dalam agenda praksis. Bukan verbalisme atau aktivisme, yang pada hakikatnya adalah penindasan.

- Ada manusia yang hanya hidup dan tak berhasil "mengada". Situasi penindasan manusia mereduksi manusia menjadi benda atau binatang. Begitulah kondisi Brazil pada tahun 1950-an dan awal 1960, yang terbenam dalam masyarakat tertutup, yang ditandai dengan mentalitas hanya hidup dan tak berhasil mengada. Situasi ini tidaklah manusiawi, bukan saja masyarakat secara umum, tetapi juga pada tingkat elite. Mereka sama-sama tidak terintegrasi. Kaum elite hidup mengambang di atas realitas,

${ }^{6}$ Paulo Freire, Pendidikan Sebagai Proses, Surat-menyurat Pedagogis Dengan Para Pendidik Guinea-Bissau (Yogyakarta: Pustaka Belajar, 2000), 15. 
sedangkan rakyat banyak juga tenggelam di dalamnya. Oleh karena itu, dalam proses perubahan sosial, kaum elite mesti merasa berkewajiban untuk mengimpor teori-teori perubahan sosial yang asing dan masyarakat juga berkewajiban untuk patuh di bawah perintah elite. Dalam istilah Freire, masyarakat mengalami massifikasi. Jelasnya, masyarakat demikian adalah masyarakat yang berhasil memasuki sejarah, tetapi kemudian dimanipulasi oleh sekelompok elite untuk tidak berpikir dan mudah dikendalikan. Oleh karena itu, masyarakat gagal atau lebih tepatnya digagalkan menjadi subjek. Padahal, orang yang gagal menjadi subjek adalah sama saja dengan manusia yang hanya bisa hidup saja (to live), sehingga perannya tak lebih dari binatang. Dalam konteks inilah, Freire, melalui distingsi Karl Jasper (filsuf eksistensialis Jerman, 1883-1969), menekankan aspek perbedaan penting antara to live (hidup) dengan to exist (ada). "Ada" atau "mengada," bagi Freire lebih dari sekadar hidup. Karena itu, "berada" atau bereksistensi (mengada) berarti tidak hanya ada di dalam dunia, tetapi juga bersama dunia. Dalam rumusan teknisnya, manusia ada bersama dunia dalam berkomunikasi. Jadi, seseorang hanya dapat bereksistensi dalam hubungannya dengan orang lain yang juga bereksistensi.

- Eksistensi manusia adalah tugas praksis. Oleh karena itu, bereksistensi yang sejati harus sejalan dengan tindakan sejati manusia. Tindakan sejati manusia adalah kesatuan dialektis antara teori dan praktik, refleksi dan aksi.

- Manusia disituasikan dalam sejarah yang tidak selesai. Manusia selalu muncul dari waktu, namun manusia tidak terkungkung dalam waktu. Inilah yang memungkinkan sejarah manusia. Secara konseptual, manusia dimungkinkan dan harus secara terus merealisasikan dirinya dalam sejarah yang tidak pernah selesai. Hal itu berarti manusia juga dikondisikan dan disituasikan oleh sejarah. Di dalam kesadarannya akan sejarah, manusia dituntut untuk terus-menerus memanusiakan sejarahnya yang belum selesai, untuk lebih menjadi human. Maka, humanisasi menjadi tugas sejarah manusia.

- Manusia mempunyai panggilan hidup yang bersifat ontologis, yaitu menjadi subjek dan "memberi nama dunia". Humanisasi menjadi tugas manusia dalam merealisasikan sejarahnya. Humanisasi secara aksiologis adalah masalah utama manusia. Keprihatinan terhadap masalah humanisasi akan segera membawa kepada pengakuan akan adanya masalah dehumanisasi. Pengakuan ini tentu saja bukan hanya bersifat ontologis, tetapi juga merupakan realitas sejarah. Humanisasi merupakan fitrah manusia. Dalam rangka proses humanisasi inilah, panggilan manusia dalam sejarah ontologis adalah menjadi subjek. Manusia yang utuh adalah manusia sebagai subjek. Sebaliknya, manusia yang hanya beradaptasi saja adalah posisi manusia sebagai objek. Adaptasi merupakan bentuk pertahanan diri yang paling rapuh. Seseorang yang hanya melulu beradaptasi tidak akan mampu mengubah dunia. Adaptasi adalah khas binatang. Jika hal itu terjadi pada manusia, maka telah terjadi gejala dehumanisasi. Oleh karena itu, dalam rangka humanisasi, manusia harus menjadi subjek. Menjadi subjek dalam hubungannya dengan dunia adalah memberi nama (to name). To name adalah to act. Dengan to act, manusia memberi arti temporal terhadap ruang geografis dengan menciptakan kebudayaan.

- Hubungan manusia dengan dunia memperlihatkan kenyataan adanya problem "dunia tema" dan "situasi batas." Menciptakan kebudayaan ditandai oleh serangkaian cita- 
cita, minat dan nilai-nilai yang hendak diwujudkan dengan mengada (to exist) dan berbuat (to act). Di sinilah tugas manusia terlihat, yakni mengenali tema-tema dunianya. Dapat atau tidaknya manusia menangkap tema ini sangat menentukan proses apakah mereka akan mengalami humanisasi atau tidak. Terjadi pengukuhan sebagai subjek atau malah jatuh menjadi objek. Jika manusia mampu menangkap tema-tema zamannya, maka manusia akan mampu campur tangan dalam menangani dunia, dan tidak tinggal sebagai pengamat. Menangani berarti secara kontinu menyingkap situasi batas yang melingkupi mereka. Situasi batas bukanlah hambatan, tetapi justru sebagai tantangan untuk diperbaharui atau humanisasi secara terusmenerus.

- Menjadi ada berarti bertindak politik untuk humanisasi. Memperbarui dunia berarti secara kontinu mewujudkan ada sebagai manusia. Oleh karena, mewujudkan ada berarti terarah kepada tindakan. Sedangkan, menjadi ada berarti mempunyai nilai politik dan bertindak politik sebagai upaya humanisasi. Dengan demikian, perumusan teknisnya adalah to exist to act politically. Dengan demikian, setiap tindakan manusia akan berarti atau memiliki arti penting bagi dirinya sendiri dan lingkungannya.

Sistematisasi 9 rumusan relasi manusia dunia itulah, yang oleh Freire diungkapkan dalam bahasa yang ringkas: Kenyataan itu dialami manusia sebagai proses. Kenyataan sebagai proses baru dapat dipahami dalam hubungan manusia dengan dunia, yang terlihat dalam bahasa-pikiran. Kemampuan untuk mewujudkan bahasa-pikiran ke dalam realitas inilah yang membedakan manusia dengan binatang. Kalau usaha mewujudkan bahasapikiran dihambat, manusia hanya hidup saja dan tak akan berhasil untuk mengada. Manusia harus mengada, karena ciri khasnya adalah eksistensi. Eksistensi manusia baru muncul dalam praksis. Praksis berarti membuat sejarah, dan karena itu merupakan panggilan hidup. Panggilan hidup manusia secara ontologis adalah menjadi subjek dan memberi nama pada dunia. Dunia baru muncul dan disadari ketika kita mampu merumuskan tema-tema zaman kita. Mewujudkan tema-tema zaman inilah yang merupakan tindakan politik manusia untuk humanisasinya.

\section{Metode Pendidikan Paulo Freire}

Freire mengawali pembahasannya dengan mengevaluasi model praktik pendidikan yang lazim berlaku. Ia menyebut model itu sebagai model pendidikan gaya bank. Model ini mengandaikan guru sebagai subjek, sedangkan murid adalah obyek seperti wadah kosong tempat deposito bank. Dalam gaya atau model ini bertemulah keadaan-keadaan sebagai berikut: tahu dan tidak tahu, memiliki dan tidak memiliki (pengetahuan), kepenuhan dan kekosongan, kekuasaan dan tanpa kekuasaan. Menurut Freire, pendidikan semacam ini hendak mempertahankan sekaligus merangsang sikap-sikap dan praktik-praktik penindasan, serta mencerminkan masyarakat yang tertindas sebagai keseluruhan. Freire menyebut ciriciri pendidikan gaya bank: ${ }^{7}$

- Guru mengajar dan murid diajar.

- Guru mengetahui segalanya, dan murid tidak mengetahui apa-apa.

\footnotetext{
${ }^{7}$ Freire, Pendidikan Kaum Tertindas, 51-52.
} 
- Guru berpikir, dan murid dipikirkan.

- Guru berbicara, dan murid mendengarkan dengan penuh ketekunan.

- Guru mengatur, dan murid diatur.

- Guru memilih dan memaksakan pilihannya, sedangkan murid hanya menurut dan menyesuaikan diri.

- Guru beraksi, dan murid sudah merasa beraksi apabila menirukan gurunya.

- Guru memilih isi program, dan murid - tanpa diminta pertimbangannya - harus menyesuaikan diri.

- Guru mencampuradukkan otoritas ilmu pengetahuan dengan otoritas profesionalnya, yang sebenarnya bertentangan dengan kebebasan muridnya.

- Guru merupakan subjek dari suatu proses belajar, sedangkan murid hanya sebagai objek belaka.

Pengandaian tersebut menjadikan murid sebagai objek yang harus diisi dan diberi makanan pengetahuan dengan kata-kata, gambaran-gambaran dan prasangka-prasangka dari pihak pendidik. Semakin patuh guru menanggung proses pengisian ini, dan murid semakin merelakan segala sesuatu yang disajikan kepada dirinya, maka pendidikan akan semakin dianggap sukses. Dalam sistem pendidikan semacam ini, guru adalah pusat segala-galanya. Murid akan mengidentifikasikan dirinya seperti gurunya sebagai prototipe ideal yang mesti diikuti. Konsekuensinya, apabila sang murid memberontak untuk diisi secara penuh, karena bahan makanan yang disajikan kepadanya itu tidak cocok dengan selera murid dan tidak memberikan kepuasan batin kepada dirinya, maka sang murid akan dianggap tidak berkembang dan bahkan akan dianggap bodoh. Sebaliknya, pendidikan akan dianggap berhasil, dengan petunjuk semakin patuhnya murid menerima dan menyimpan peruntungan nasib, yang sebenarnya ditentukan dari luar, program-program yang berisikan pengetahuan yang asing dengan realitas murid, yang dilakukan dengan bahasa dan penilaian yang asing. Akibatnya, manusia yang terdidik akan merupakan manusia yang terasing dengan dirinya sendiri dan lingkungannya. Freire menyebutkan pendidikan semacam ini akan menciptakan necrophily. Ini adalah istilah psikologi Erich Fromm (Psikoanalist Jerman, 1900-1980) yang menunjuk pada kecintaan terhadap sesuatu yang bersifat destruktif, dan senang kepada yang tidak hidup (kematian). ${ }^{8}$

Menurut Freire, metode pendidikan harus berorientasi pada pengenalan (konsientisasi) diri manusia dan dirinya sendiri. Pengenalan diri ini tidak cukup bersifat subjektif belaka, tetapi juga objektif sekaligus. Kebutuhan objektif untuk mengubah keadaan dunia yang tidak manusiawi selalu memerlukan kemampuan subjektif. Dengan demikian, objektivitas dan subjektivitas bukanlah dua entitas yang saling bertentangan. Keduanya merupakan dialektika yang berjalan konstan dalam diri manusia dalam hubungannya dengan kenyataan yang saling bertentangan.

Kedua fungsi dialektis ini, baik secara subjektif maupun objektif, tanpa dialektika justru akan menjebak kita pada kesalahan berpikir. Misalnya, objektivitas dalam pengertian penindas bisa berarti subjektivitas dalam pengertian tertindas. Di sinilah pentingnya pemahaman tersebut untuk suatu pendidikan sebagai Pendidikan Kaum Tertindas. Gaya pendidikan Freire ini diciptakan bukan untuk kaum tertindas dalam rangka memulihkan kembali sisi kemanusiaan mereka yang hilang, tetapi untuk suatu perjuangan melawan 
penindasan, dalam situasi di mana manusia dan dunia berada dalam interaksi. Dalam konteks ini, diperlukan praksis. Dalam praksis itu sendiri, ada salah satu unsur yang terpenting, yakni pengembangan kesadaran. ${ }^{9}$

Dalam rangka pengembangan kesadaran ini, kata kunci yang dipakai Freire adalah pengembangan kesadaran ke arah masyarakat terbuka. Oleh sebab itu, pendidikan harus melibatkan tiga unsur sekaligus dalam suatu hubungan dialektis, yakni guru-yang-murid, murid-yang-guru dan realitas dunia. Yang pertama dan kedua merupakan subjek yang sadar, sedangkan yang ketiga adalah objek yang disadari.

Sambil mengacu pada pandangan psikoanalisa Eric Fromm, Freire meminjam istilah biophily, yakni suatu orientasi kehidupan total, suatu cara hidup yang menyeluruh dan mencintai perkembangan ke arah yang lebih manusiawi, dengan akal budi dan cinta kasih untuk menjadikan pendidikan menjadi kekuatan penyadar dan pembebas manusia. Kekuatan penyadar dan pembebas manusia harus menjadi tekanan dan orientasi utama.

Lantas, bagaimana pendidikan yang mengarah kepada biophily? Inilah pendidikan yang dipikirkan dan telah dipraktekkan oleh Freire, sekaligus menjadi ideal dari pendidikan sebagai praktik pembebasan. Pendidikan seperti ini disebut oleh Freire sebagai problem posing education (pendidikan-hadap-masalah), yakni pendidikan yang mengutarakan atau mengemukakan problem-problem aktual. Pendeknya, pendidikan adalah menghadapkan masalah. Caranya sebagai berikut: ${ }^{10}$

- Melalui kodifikasi dan dekodifikasi. Dalam tahap ini dilakukan penelitian tentang dunia tema-tema atau terhadap kosa kata. Namun, kosa kata yang dimunculkan harus mengandung situasi batas. Tema-tema tersebut kemudian dipadatkan dalam visualisasi, misalnya gambar-gambar.

- Melalui diskusi kultural. Setelah tema-tema dipilih, dikodifikasikan dan dipadatkan dalam bentuk visualisasi, maka tema-tema tersebut didekodifikasikan serta sodorkan kepada peserta. Misalnya, gambar disodorkan untuk didiskusikan. Diskusi ini begitu penting untuk menumbuhkan sikap penghargaan terhadap realitas. Karena itu, peserta pun mulai membicarakan tentang realitas.

- Melalui aksi kultural. Diskusi akan menghasilkan rekomendasi untuk tindakan praksis. Tahap aksi kultural adalah tahap praksis yang sesungguhnya, di mana tindakan perseorangan maupun bersama menjadi bagian langsung dari realitas.

Ketiga tahap ini merupakan hal yang sangat penting untuk memahami metode Freire. Secara ringkas, "pendidikan hadap masalah" adalah sebagai berikut:

Guru belajar dari murid dan murid belajar dari guru. Guru menjadi rekan murid yang melibatkan diri, dan menstimulus daya pemikiran kritis murid-muridnya. Karenanya, mereka saling memanusiakan. Guru dan murid dapat mengembangkan kemampuannya untuk mengerti secara kritis mengenai dirinya sendiri dan dunianya. Dengan demikian, mereka saling memanusiakan. Dengan "pendidikan hadap masalah," selalu terbuka rahasia realitas yang menantang dan menuntut respons. Dengan respons semacam itu, guru dan murid dibawa kepada dedikasi yang sesungguhnya. Bagi mereka, pengetahuan adalah komitmen. ${ }^{11}$

\footnotetext{
${ }^{9}$ Freire, 61.

${ }^{10}$ Paulo Freire, Pendidikan Kaum Tertindas, 119-22.

11 Munawar-Rachman, "Pendidikan Sebagai Proses Transformasi Sosial", 514
} 
Dengan demikian, pendidikan hadap masalah adalah pendidikan yang dialogis. Setiap waktu, pendidikan semacam ini akan diarahkan kepada tindakan yang selanjutnya direfleksikan bersama. Daurnya adalah aksi-refleksi dan kemudian refleksi-aksi. Dari refleksi ini diciptakan tindakan baru. Pada proses resiprokal yang berjalan secara terusmenerus inilah yang disebut dengan tindakan praksis. Karena itu, pendidikan menjadi daur berpikir dan bertindak yang terus-menerus, sepanjang hayat melekat dalam badan manusia.

\section{Inspirasi Pemikiran Paulo Freire Bagi Pendidikan Tinggi Di Indonesia}

Karya Freire memang berada dalam taraf pendidikan yang berkaitan dengan pemberantasan buta huruf. Dari konteks inilah Freire berhasil membangun sebuah perspektif teoretis yang luar biasa tentang teori kependidikan dan teori kebudayaan sebagai aksi pembebasan. Kata Freire, kalau kaum penindas mempunyai teori perubahan sosial yang dipakai untuk menindas kaum tertindas, diperlukan pula teori pendidikan (dan juga teori kebudayaan) sebagai teori perubahan (transformasi) sosial untuk kaum tertindas. Itulah sebabnya, pendidikan kaum tertindas karya Freire dimaksudkannya sebagai bagan teoretis untuk perubahan sosial dari kalangan tertindas.

Di awal kariernya sebagai pengajar, Paulo Freire mengupayakan agar para siswa mempunyai kemampuan untuk membaca dan menulis. Bagi Freire, dua kemampuan ini merupakan prasyarat agar nanti bisa berpartisipasi dalam kegiatan publik di bidang politik, yakni pemilihan umum. Maka, pendidikan merupakan pintu masuk untuk memberantas budaya bisu dan diam atas realitas politik yang membelenggu dan menindas. Sekiranya semua program pembangunan yang dibuat oleh pemerintah tidak didasarkan kepada proses swadaya dan partisipasi masyarakat, akibatnya adalah alienasi masyarakat, penindasan dan kematian. Penyelenggaraan pemerintahan itu bisa otoriter dan represif, hingga akhirnya menciptakan lapisan atau kelompok yang super elite di bidang ekonomi dan politik. Kesenjangan sosial-ekonomi semakin melebar, yang saatnya semakin memperlebar pula kantong-kantong kemiskinan. Di tingkat individu ada ketidakmampuan mengaktualisasikan potensi diri kemanusiaannya.

Harun Nasution, salah seorang tokoh pendidikan Indonesia, pernah mengemukakan pemikiran kritisnya atas praktik pendidikan di Indonesia. Bagi Harun, ada kecenderungan para siswa diisi dari otak ke otak (transfer of head) dan sedikit sekali menyentuh aspek nilai (transfer of values). Kesannya para siswa dikondisikan pada belajar demi kelulusan bukan belajar demi kehidupan. Hal ini terjadi karena para siswa dan juga para pendidik terbelenggu dengan kurikulum yang padat. Akibatnya, para siswa tidak menjadi dewasa, tidak dipersiapkan untuk mampu merespons dan memecahkan masalah dirinya dan masalah orang lain. $^{12}$

Menurut Badan Pusat Statistik (BPS) tahun 2020, presentasi dan jumlah penduduk buta huruf di Indonesia mencapai 1,71 \% atau 2.961.060 jiwa dari total penduduk Indonesia. Data ini serta-merta mengingatkan kita akan belum tercapainya cita-cita dan tujuan Pendidikan nasional yakni mencerdaskan seluruh masyarakat Indonesia. Kenyataan buta huruf ini secara terang-benderang, dalam perspektif Freire, menegaskan bahwa di Indonesia

\footnotetext{
${ }^{12}$ Suwito dan Fauzan (eds.), Sejarah Pemikiran Para Tokoh Pendidikan (Bandung: Penerbit Angkasa, 2003), 409-410.
} 
ada hampir 3 juta penduduk yang berada dalam kondisi tertindas. Agak mencengangkan dan membuka mata kita semua bahwa data di atas menegaskan bahwa sekitar $22 \%$ dari jumlah tersebut di atas terdapat di Papua. Apakah data buta huruf di Papua ini mewakili gejolak Papua pada akhir-akhir ini yang sarat dengan pemberontakan terhadap NKRI karena mereka merasa ditindas?

Pendidikan-hadap-masalah ala Freire yang melihat realitas di luar dirinya sebagai pokok bahasan dalam pendidikan bisa dibahasakan secara lain, yakni pendidikan yang berbasis lingkungan dan berbasis kemasyarakatan. Yang dimaksud dengan dua basis ini adalah lingkungan alam semesta dan kebudayaan masyarakat sekitar. Pendidikan berbasis lingkungan adalah pendidikan yang mengangkat alam semesta sebagai yang hal yang memberi makna dan pengaruh bagi siswa. Sementara itu, pendidikan yang berbasis kemasyarakatan adalah pendidikan yang memadukan sekolah dan masyarakat, dalam pengertian membawa sekolah ke dalam masyarakat dan sebaliknya membawa masyarakat ke dalam sekolah demi mencapai tujuan pendidikan. ${ }^{13}$

Pada tahun 1980-an digalakkan di Indonesia yang disebut Cara belajar Siswa Aktif (CBSA), yakni pendidikan yang menekankan keterlibatan kemampuan siswa baik secara fisik, mental, intelektual maupun emosional sehingga diperoleh hasil belajar yang merupakan paduan antara aspek kognitif, afektif dan psikomotor yang utuh. Dalam CBSA diandaikan dan sungguh dituntut partisipasi aktif dari subyek didik/siswa, sementara guru/pengajar berperan sebagai motivator. ${ }^{14}$

Dewasa ini di dunia pendidikan Indonesia muncul ungkapan Belajar MerdekaKampus Merdeka. Istilah ini digaungkan oleh pemerintah Indonesia melalui Kementerian Pendidikan, Kebudayaan, Riset dan Teknologi pada tahun 2020. Untuk tingkat SMA/SLTA, kebijakan Merdeka Belajar mendorong kepala sekolah, guru, orang tua dan pemerintah daerah agar mampu bergotong-royong untuk mencari dan menemukan solusi yang efektif, efisien dan cepat terhadap kondisi, tantangan dan permasalahan pendidikan di masingmasing sekolah, khususnya dalam rangka meningkatkan kualitas proses belajar siswa. Kepala sekolah, guru, orang tua dan pemerintah daerah merasa memiliki dan bertanggungjawab terhadap pengelolaan Pendidikan. ${ }^{15}$

Di level perguruan tinggi, kampanye Kampus Merdeka memberikan tantangan dan kesempatan untuk pengembangan kreativitas, kapasitas, kepribadian, dan kebutuhan mahasiswa, serta mengembangkan kemandirian dalam mencari dan menemukan pengetahuan melalui kenyataan dan dinamika lapangan seperti persyaratan kemampuan, permasalahan riil, interaksi sosial, kolaborasi, manajemen diri, tuntutan kinerja, target dan pencapaiannya. ${ }^{16}$ Proses pembelajaran dalam Kampus Merdeka merupakan salah satu perwujudan pembelajaran yang berpusat pada mahasiswa (student centered learning) yang sangat esensial. Pembelajaran dalam Kampus Merdeka memberikan tantangan dan

\footnotetext{
${ }^{13}$ Prof.Dr. Oemar Hamalik, Proses Belajar Mengajar (Jakarta: PT. Bumi Aksara, 2001), 194-197.

${ }^{14}$ Dra. Subandijah, Pengembangan dan Motivasi Kurikulum (Jakarta: PT. Raja Grafindo Persada, 1993), 112-113.

${ }^{15}$ Direktorat Sekolah Menengah Atas, Dirjen PAUD, Dikdas, Dikmen, Buku Saku Merdeka Belajar: Prinsip dan Implementasi Pada Jenjang Pendidikan SMA (Jakarta: Direktorat Sekolah Menengah Atas, Dirjen PAUD, Dikdas, Dikmen, 2020), 9-10.

${ }^{16}$ Direktorat Jenderal Pendidikan Tinggi Kementerian Pendidikan dan Kebudayaan, Buku Panduan Merdeka Belajar Kampus Merdeka (Jakarta: Direktorat Jenderal Pendidikan Tinggi Kemendikbud RI, 2020), 4.
} 
kesempatan untuk pengembangan kreativitas, kapasitas, kepribadian, dan kebutuhan mahasiswa, serta mengembangkan kemandirian dalam mencari dan menemukan pengetahuan melalui kenyataan dan dinamika lapangan seperti persyaratan kemampuan, permasalahan ril, interaksi sosial, kolaborasi, manajemen diri, tuntutan kinerja, target dan pencapaiannya.

Merdeka Belajar-Kampus Merdeka bertujuan mendorong mahasiswa untuk menguasai berbagai keilmuan yang berguna untuk memasuki dunia kerja. Kampus Merdeka memberikan kesempatan bagi mahasiswa untuk memilih mata kuliah yang akan mereka ambil. Konsep ini juga memberikan keleluasaan kepada mahasiswa untuk belajar di luar kampus. Konsep tersebut terus dikembangkan sebagai upaya untuk mendapatkan calon pemimpin masa depan yang berkualitas. Jadi, mahasiswa nantinya secara tidak langsung akan diajak untuk belajar caranya hidup di lingkungan masyarakat. Pada dasarnya kebijakan tersebut bertujuan untuk dapat mengenalkan adanya dunia kerja pada mahasiswa sejak dini. Sehingga kemudian mahasiswa akan jauh lebih siap kerja setelah nantinya lulus dari sebuah perguruan tinggi yang tersedia. Ada 4 Poin Kebijakan Kampus Merdeka: ${ }^{17}$

- Mengubah PTN Satuan Kerja menjadi sebuah PTN Bantuan Hukum. Dengan PTN BH semua kampus dapat berkompetisi di panggung dunia, mendapatkan keleluasaan untuk dapat bermitra dengan dunia industri, adanya keleluasaan pihak kampus untuk melakukan proyek komersial, juga dapat melakukan perubahan pada pengaturan keuangan dengan cepat sesuai dengan kebutuhan.

- Adanya penyederhanaan pada akreditasi perguruan tinggi. Salah satu kebijakan lainnya yang diterapkan dalam kampus yang merdeka adalah adanya penyederhanaan pada akreditasi perguruan tinggi. Kebijakan ini berkaitan dengan program reakreditasi yang pada dasarnya bersifat otomatis untuk semua peringkat dan juga bersifat sukarela bagi perguruan tinggi. Pada dasarnya dalam penerapan kampus yang merdeka, ke depannya akreditasi tetap berlaku selama lima tahun dan bisa diperbaharui secara otomatis. Adanya akreditasi A akan diberikan pada setiap perguruan tinggi yang nantinya bisa berhasil mendapatkan akreditasi internasional.

- Membuka prodi baru. Adanya otonomi bagi setiap perguruan tinggi baik PTN ataupun PTS untuk membuka atau mendirikan sebuah program studi yang baru. Otonomi pendirian prodi baru nantinya akan diberikan jika sebuah PTN atau PTS telah memiliki akreditasi A ataupun B. Hak otonom tersebut diberikan jika telah melakukan kerjasama dengan organisasi atau universitas lain.

- Adanya kegiatan dua semester di luar kampus. Adanya kebijakan untuk melakukan kegiatan selama dua semester di luar kampus pada dasarnya menjadi sebuah bentuk kemerdekaan yang didapatkan oleh mahasiswa. Kegiatan diluar kampus bisa dilakukan dengan berbagai macam hal mulai dari magang atau praktik pada suatu organisasi. Mengajar pada sebuah sekolah di daerah terpencil pada dasarnya juga menjadi salah satu contoh penerapan kegiatan dua semester di luar kampus. Mahasiswa juga bisa melakukan kegiatan membantu riset atau penelitian dosen serta membantu mahasiswa S2 dan S3 melakukan penelitian. Adanya kebijakan kampus merdeka yang memberikan keleluasaan kepada mahasiswa untuk melakukan kegiatan di luar kelas akan mendorong mereka untuk mandiri. Kampus yang

\footnotetext{
${ }^{17}$ Direktorat Jenderal Pendidikan Tinggi Kementerian Pendidikan dan Kebudayaan, 7.
} 
memberikan keleluasaan kepada mahasiswa untuk kegiatan di luar kelas akan membantu mereka lebih tahu penerapan ilmunya dalam suatu bidang kerja. Ini akan membantu mahasiswa untuk kemudian bisa lebih siap menghadapi dunia kerja yang saat ini semakin sulit.

Dengan demikian, dalam praktik dan pedoman pendidikan di Indonesia selama ini, sebagaimana tertuang dalam Pendidikan Berbasis Lingkungan dan Kemasyarakatan, Cara Belajar Siswa Aktif (CBSA) dan konsep Merdeka Belajar-Kampus Merdeka, kita melihat kesamaannya dengan model pendidikan Paulo Freire. Dalam konsep-konsep praktek pengajaran di Indonesia kita menemukan model pendidikan hadap masalah ala Paulo Freire yang memungkinkan para siswa dan mahasiswa untuk secara bebas dan kreatif mengenal kemampuan diri dan realitas masalah secara obyektif-kontekstual dan kemudian merespons masalah secara tepat dalam bentuk karya-karya perubahan yang unggul dan produktif.

\section{Daftar Kepustakaan}

Budy Munawar-Rachman. "Pendidikan Sebagai Proses Transformasi Sosial:Teologi Perlu Belajar dari Filsafat Paulo Freire.” Dalam Islam Pluralis Wacana Kesetaraan Kaum Beriman, 493-95. Jakarta: PT. Raja Grafindo, 2004.

Direktorat Jenderal Pendidikan Tinggi Kementerian Pendidikan dan Kebudayaan. Buku Panduan Merdeka Belajar - Kampus Merdeka. Jakarta: Direktorat Jenderal Pendidikan Tinggi Kemendikbud RI, 2020.

Direktorat Sekolah Menengah Atas, Dirjen PAUD, Dikdas, Dikmen. Buku Saku Merdeka Belajar: Prinsip dan Implementasi Pada Jenjang Pendidikan SMA. Jakarta: Direktorat Sekolah Menengah Atas, Dirjen PAUD, Dikdas, Dikmen, 2020.

Dra. Subandijah. Pengembangan dan Motivasi Kurikulum. Jakarta: PT. Raja Grafindo Persada, 1993.

Paulo Freire. Pendidikan Kaum Tertindas. Jakarta: LP3ES, 1985.

. Pendidikan Sebagai Praktek Pembebasan. Jakarta: PT. Gramedia, 1985.

—. Pendidikan Sebagai Proses, Surat-menyurat Pedagogis Dengan Para Pendidik Guinea-Bissau. Yogyakarta: Pustaka Belajar, t.t.

Paulo Freire dkk. Menggugat Pendidikan Fundamentalisme Konservatif Liberal Anarkis . Yogjakarta: Pustaka Belajar, 1999.

Prof.Dr. Oemar Hamalik. Proses Belajar Mengajar. Jakarta: PT. Bumi Aksara, 2001.

Suwito dan Fauzan (eds.). Sejarah Pemikiran Para Tokoh Pendidikan. Bandung: Penerbit Angkasa, 2003. 